Keywords: Stalking Protection Act 2019, stalking protection orders, behaviour orders, stalking, law-making.

Abstract: In 2019, Parliament enacted the Stalking Protection Act. The Act introduces the stalking protection order; a civil measure the breach of which is an offence. The role of courts in assessing whether similar behaviour orders are penalties has attracted significant scholarly attention. In this article, I instead examine the roles of Government and Parliament in developing the stalking protection order. My central contention is that the Home Office undertook a problematic consultation and the issues to which it gave rise were not addressed in later parliamentary debates. The result was the enactment of a coercive measure of unclear purpose and questionable efficacy. Assessing the roles of the executive and legislature in developing the SPO also allows for fresh insight into wider discussions of behaviour orders. Specifically, I question the language of 'prevention' that is ever-present in such discussions and describe an important development for debates on whether behaviour orders are penalties. Word count excluding footnotes: 8,725.

Word count including footnotes: 11,146 .

\title{
The Problematic Development of the Stalking Protection Order
}

Rory Kelly*

Since the enactment of the anti-social behaviour order (ASBO) in 1998, Parliament has introduced hybrid behaviour orders with remarkable frequency. ${ }^{1}$ In 2019 alone, Government

\footnotetext{
${ }^{*}$ Faculty of Laws, UCL. My thanks to Harry Annison, Andrew Ashworth, Karl Laird, Leila Tai, Lucia Zedner and the anonymous reviewers for their insightful comments on earlier drafts of this article. All URLs were last accessed on 6 September 2019.

${ }^{1}$ Crime and Disorder Act 1998, s 1.
} 
has moved to introduce a domestic abuse protection order; ${ }^{2}$ and Parliament has extended the scope of the serious crime prevention order, ${ }^{3}$ enacted the knife crime protection order ${ }^{4}$ and also enacted the stalking protection order (SPO). ${ }^{5}$ The last order is the subject of this article. What unites hybrid behaviour orders is that they can be imposed following proceedings that apply civil evidential rules, but breach is a criminal offence. ${ }^{6}$ Courts have repeatedly assessed whether particular hybrid behaviour orders constitute penalties. ${ }^{7}$ If an order does constitute a penalty, proceedings for its imposition will attract additional human rights safeguards such as the ban on retrospective punishment and heightened fair trial rights. ${ }^{8}$ Much of the existing literature queries whether the appellate courts have been right to classify various hybrid behaviour orders as non-penal. ${ }^{9}$ In this article, I turn from the work of the courts, to assess the

\footnotetext{
${ }^{2}$ Domestic Abuse Bill 2017-19 (HC Bill 422), cls 26-46.

${ }^{3}$ Counter-Terrorism and Border Security Act 2019, s 14.

${ }^{4}$ Offensive Weapons Act 2019, ss 14-33.

${ }^{5}$ Stalking Protection Act 2019, s 1.

${ }^{6}$ Hybrid behaviour orders, form part of a wider taxonomy of behaviour orders. See, R. Kelly and A. Ashworth, 'State Responses to Criminal Offences in England and Wales and the Problem of Equality' in M. Dyson and B.
} Vogel (eds), The Limits of Criminal Law (Cambridge: Intersentia 2018). The possible exception to the use of civil evidential rules in the initial proceeding is the criminal evidential standard: $R$ (McCann) $v$ Manchester Crown Court [2003] 1 AC 787 [37] (Lord Steyn), [81]-[83] (Lord Hope), [114] (Lord Hutton).

${ }^{7}$ The leading judgment remains that of the House of Lords in McCann n 6 above. See also the recent judgment of the Court of Appeal on gang injunctions and anti-social behaviour injunctions: Birmingham City Council v Jones (Secretary of State for the Home Department intervening) [2019] QB 521. For comment, R. Kelly, 'Reconsidering the Punishment-Prevention Divide' (2019) 135(Jan) LQR 12.

${ }^{8}$ The ban on retrospective punishment is contained in article 7 of the European Convention of Human Rights and the heightened criminal fair trial safeguards are contained in article 6(2)-(3).

${ }^{9}$ Examples include, A. Ashworth, 'Social Control and "Anti-Social Behaviour": The Subversion of Human Rights?' (2004) 120(Apr) LQR 263'; C. Bakalis, 'Asbos, "Preventative Orders” and the European Court of 
respective roles of Government and Parliament in the development of the SPO. Given the hybrid behaviour order model continues to proliferate and to be classed as non-penal, further insight into how and why these coercive measures are developed is needed.

Stalking itself is an insidious behaviour. The Crime Survey for England and Wales reports that around 1/5 women and 1/10 men have been the victim of stalking. ${ }^{10}$ In addition, stalking garnered significant media attention after a string of high profile incidents, including the stalking of Newsnight presenter Emily Maitlis, and singer Lily Allen. ${ }^{11}$ Given this, it is little wonder that Government moved to address stalking. In particular, it moved to tackle 'stranger stalking', that is stalking where no or only a casual relationship exists between the stalker and their victim. In December 2015, the Home Office consulted on the introduction of the SPO. ${ }^{12}$ In December 2016, it then produced a Summary of Responses which set out plans to legislate to introduce the SPO. ${ }^{13}$ The Stalking Protection Bill received its first reading in July 2018

Human Rights' [2007] (4) EHRLR 427; G. Pearson, 'Hybrid Law and Human Rights - Banning and Behaviour Orders in the Appeal Courts' (2006) 27 Liverpool Law Review 125.

${ }^{10}$ Office of National Statistics, Crime in England and Wales Annual Supplementary Tables (2019) table S40. The definition of 'stalking' relied on in the survey is not identical to the legal definition: Office of National Statistics, User Guide to Crime Statistics for England and Wales (2019) 51 and 76. The proportion of men and women stalked were similar when government consulted on the SPO: Office of National Statistics, Crime in England and Wales Annual Supplementary Tables (2016) table 39.

11 O. Bowcott, 'Maximum Sentence for Stalking to Rise to 10 Years' (Guardian.co.uk, 2017) at https://www.theguardian.com/law/2017/jan/06/maximum-sentence-for-stalking-to-rise-to-10-years.

${ }^{12}$ Home Office, Introducing a Stalking Protection Order - a Consultation (2015).

${ }^{13}$ Home Office, Introducing a Stalking Protection Order - a Consultation: Summary of Responses (2016) 9; Home Office, Impact Assessment: Introducing a Stalking Protection Order - a Consultation: Summary of Responses (2016). 
before it was enacted in March 2019. The introduction of the order forms part of the Government's wider plans to tackle violence against women and girls. ${ }^{14}$

The purpose of this article is not to critique the Government's laudable aim of tackling stalking. Instead, it is to critically appraise the development of the SPO and the respective roles of Government and Parliament in this process. I contend that problems with the consultation undertaken by the Home Office resulted in a commitment to introduce a coercive measure of unclear purpose and questionable efficacy. I also maintain that these issues were not resolved in Parliament. Perhaps inevitably, there was not significant appetite to challenge and rethink a measure that aimed to prevent stalking.

The article is split into seven sections. The first provides context by detailing and appraising the SPO as introduced in the Stalking Protection Act 2019 (the 2019 Act). Sections two to five then trace the development of the order from a policy suggestion to the enactment of the Stalking Protection Bill. The second section engages with the parliamentary debate that preceded the consultation on whether to introduce an SPO. The third critiques the Consultation Paper itself. The fourth examines the later Home Office Summary of Responses and the corresponding Impact Assessment. The section also draws on publicly available responses to the consultation. The parliamentary debate, or perhaps better consensus, on the need to enact the Stalking Protection Bill is the subject of the fifth section. Together these sections on the history of the 2019 Act draw out the uncertainty as to the precise purpose of the SPO and the limits on the examination of its likely efficacy. In light of this assessment of the SPO, section six makes two more general points on hybrid behaviour orders. First, it suggests we need to challenge the problematic language of prevention and protection that is ever-present in discussions of behaviour orders. Secondly, it argues that Government and the legislature have

\footnotetext{
${ }^{14}$ Home Office, 'Violence Against Women and Girls' at https://www.gov.uk/government/policies/violenceagainst-women-and-girls.
} 
an under-realised, but significant role in establishing how easy or difficult hybrid behaviour orders are to impose. The seventh section aims to reconcile the work in this article with wider literature on behaviour orders and the courts. More specifically, it comments on the intertwined roles of Government, Parliament and the courts in the perpetuation of the behaviour order model.

\section{The Stalking Protection Act 2019}

The 2019 Act introduces the SPO; it does not provide a more general response to stalking. ${ }^{15}$

The order is available on complaint by a chief officer of the police to a magistrates' court. ${ }^{16} \mathrm{~A}$ conviction is, therefore, not a prerequisite to the imposition of the order. The court may impose an SPO if satisfied three requirements are met:

(a) the defendant has carried out acts associated with stalking, (b) the defendant poses a risk associated with stalking to another person, and

(c) the proposed order is necessary to protect another person from such a risk (whether or not the other person was the victim of the acts mentioned in paragraph (a)). ${ }^{17}$

The 2019 Act references the list of examples of acts associated with stalking in section

2A of the Protection from Harassment Act 1997. The examples are as follows:
(a) following a person,
(b) contacting, or attempting to contact, a person by any means,
(c) publishing any statement or other material-
(i) relating or purporting to relate to a person, or
(ii) purporting to originate from a person,
(d) monitoring the use by a person of the internet, email or any other form of electronic communication,
(e) loitering in any place (whether public or private),
(f) interfering with any property in the possession of a person,
(g) watching or spying on a person.

\footnotetext{
15 The 2019 Act does not, at the time of writing, have a commencement date.

162019 Act, s 1(1).

172019 Act, s 2(1).
} 
These examples do not limit what may constitute a behaviour associated with stalking. This is the third occasion on which Parliament has left 'stalking' undefined when it may have been thought appropriate to define the term. The first was when the legislature introduced the stalking offences in $2012,{ }^{18}$ and the second was when it doubled the maximum sentence for stalking involving fear of violence or serious alarm or distress to ten years' imprisonment in 2017. ${ }^{19}$ To justify the decision once again not to define stalking, Sarah Wollaston MP - who introduced the Stalking Protection Bill - said the means by which stalking could be committed are 'rapidly evolving' so flexibility is needed. ${ }^{20}$ This position is open to question. By comparison, the manners in which theft and fraud can be committed may change with technology, but this does not mean that it is impossible to articulate a reasonably clear conception of the scope of either offence. ${ }^{21}$ The uncertainty surrounding the term 'stalking' will be further examined in later sections to the extent that it relates to the imposition of the SPO.

With regard to the second imposition requirement, the 2019 Act specifies that a risk associated with stalking may be in respect of either physical or psychological harm, and can apply to acts that appear harmless in themselves, where the defendant knew or ought to have known they

\footnotetext{
${ }^{18}$ Protection from Harassment Act 1997, ss 2A and 4A, as added by the Protection of Freedoms Act 2012, s 111(1)-(2).

19 Protection from Harassment Act 1997, s 4A(5)(a) as substituted by the Policing and Crime Act 2017, s 175(1)(b).

${ }^{20}$ HC Deb vol 649 col 117123 November 2018.

${ }^{21}$ Though, of course, the meaning of the terms in the elements of these offences are not beyond debate. On current issues with the meaning of dishonesty, see K. Laird and D. Ormerod, 'Ivey v Genting Casinos - Much Ado About Nothing?' in D. Clarry, The UK Supreme Court Yearbook (UK: 2017-2018 legal year, vol 9, Appellate Press 2019).
} 
were unwelcome to the other person. ${ }^{22}$ In consequence, a person may be made subject to an SPO when they have caused no harm and did not know what they were doing was unwelcome. The explanatory notes that accompanied the Stalking Protection Bill do not provide examples of scenarios that may lead to the imposition of an SPO. ${ }^{23}$ This is in-keeping with the ambiguity over what gap in the law the order was meant to address during its development; a point I will pick-up in the following sections.

An SPO may contain restrictions and/or requirements. Example restrictions from the explanatory notes to the Bill include entering a location where the victim resides, contacting the victim on social media, and physically approaching the victim. ${ }^{24}$ Example requirements include attendance at a perpetrator intervention programme, a mandatory mental health assessment and participation in restorative justice. ${ }^{25}$ Each restriction and requirement must last for two years and may be indefinite. ${ }^{26}$ Such restrictions and requirements have the potential to be very burdensome for recipients particularly when multiple conditions are imposed in combination. Breach of a restriction or requirement, without reasonable excuse, is an offence with a maximum of five years' imprisonment on indictment and 12 months on summary conviction. ${ }^{27}$ The recipient will also be subject to notification requirements: they must notify the police of their name and home address, and may be required to allow the police to take their fingerprints and a photograph of them. ${ }^{28}$ Failure to comply with the notification requirements

\footnotetext{
222019 Act, s 1(4).

${ }^{23}$ Explanatory Notes to the Stalking Protection Bill (HL Bill 145).

24 ibid para 26.

25 ibid para 27.

262019 Act, s 3 .

272019 Act, s 8(1).

282019 Act, s 10 .
} 
or knowingly providing false information, is an offence with the same maxima as the breach offence. ${ }^{29}$ Beyond these formal effects, the imposition of an SPO may have severe collateral consequences such as stigmatising the recipient. ${ }^{30}$ Similarly, Jeremy Horder maintains there is 'obviously great stigma' in the imposition of a sexual harm prevention order, another hybrid behaviour order that can be imposed on application to a magistrates' court. ${ }^{31}$ The SPO can thus have severe effects on the recipient and exposes them to further serious consequences if breached.

\section{Parliamentary debate preceding the consultation}

Mention was first made of introducing an SPO, then a 'stalking and harassment protection order', by Karen Bradley MP - a Home Office junior minister at the time - in September 2015. ${ }^{32}$ The comment was made in a parliamentary debate on the protection of victims of stalking. ${ }^{33}$ The debate was led by Alex Chalk MP after one of his constituents, Eleanor Aston, had been the victim of prolonged and serious stalking by Raymond Knight. It is worth detailing

\footnotetext{
${ }^{29} 2019$ Act, s 11(1). However, section 154 of the Criminal Justice Act 2003 is not in force. The section would extend magistrates' sentencing powers from six months to twelve months' imprisonment.

${ }^{30}$ Zachary Hoskins has recently provided an excellent account of the collateral consequences of conviction, in which he comments '[collateral consequences] may be more burdensome than the sentences themselves and often remain in effect well after the sentences have ended.' The collateral consequences of imposing a behaviour order, may have comparable effects. Z. Hoskins, Beyond Punishment? A Normative Account of the Collateral Legal Consequences of Conviction (OUP 2019) 7.

${ }^{31}$ J. Horder, Ashworth's Principles of Criminal Law (Oxford: OUP, 9th edn, 2019) 19. The sexual harm prevention order was introduced by Sexual Offences Act 2003, s 103A.

${ }^{32}$ HC Deb vol 509 col 130417 September 2015.

${ }^{33}$ HC Deb vol 509 col 130017 September 2015.
} 
Knight's stalking. ${ }^{34}$ Knight slashed the tyres of Aston's husband's car, he showed up at the birthday party of Aston's daughter, and tampered with the family's gas-line and water pipes. These events formed part of a campaign of more than 100 incidents that lasted over seven years. The campaign persisted despite a restraining order. Knight was later convicted for eight breaches of the order and criminal damage. Yet while released on licence, Knight continued to breach the order. He was then convicted of breach of the order again and for stalking; and given a sentence to run concurrently with that to be served on revocation of his licence. At sentencing, His Honour Judge Tabor was frustrated that he could not impose a longer sentence than five years for the stalking due to the relevant maximum and restrictions on consecutive sentences. ${ }^{35}$ Against this background, Chalk argued that the maximum sentence for stalking involving fear of violence or serious alarm or distress ought to be increased to ten years' imprisonment. ${ }^{36}$ When placed in the context of Chalk's speech and recommendations, Bradley's response necessitates scrutiny. What was argued for was a heightened maximum sentence, what was initially offered was a new behaviour order.

Later in the debate, Chalk suggested restraining orders are an ineffective means by which to address stalking because stalkers regularly breach them: 'it is in the nature of such offending

\footnotetext{
${ }^{34}$ This summary draws from Chalk's comments in parliamentary debate and a later report Chalk co-authored with Richard Graham MP: HC Deb vol 509 cols 1300-1302 17 September 2015; A. Chalk and R. Graham, Stalking: The Case for Extending the Maximum Penalty (2016).

${ }^{35}$ On consecutive sentences, see A. Ashworth, Sentencing and Criminal Justice (Cambridge: CUP, 6th edn, 2015) ch 8 . The stalking appears to have been charged as either aggravated harassment or aggravated stalking under the Protection from Harassment Act 1997, s 4 or s 4A respectively. The maximum sentence for both offences was five years' imprisonment at the time.

${ }^{36}$ HC Deb vol 509 col 130017 September 2015. The relevant offence is contained in the Protection from Harassment Act 1997, s 4A.
} 
that offenders ignore court orders however they are badged. ${ }^{37}$ Yet this only led Bradley to respond that there was a need for more behaviour orders and to reiterate the need for early intervention.

My hon. Friend is right. In the case that he has raised, the offender was given a restraining order banning him from 11 counties. However, we need to look at whether we can bring in more civil orders in addition to the criminal justice legislation. Anything we can do to stop offending at the earliest opportunity and prevent it from becoming a prolonged campaign would be positive. The example he has cited really brings home the fact that we need to intervene sooner, including by identifying the signs of such behaviour as soon as possible and deciding whether any measures can be used. ${ }^{38}$

Since the debate, the maximum sentence for stalking involving fear of violence or serious alarm or distress has been increased in line with Chalk's recommendation. ${ }^{39}$ For present purposes, the important point is that the debate emphasizes Government's early interest in introducing a new behaviour order, despite Chalk having raised the debate to draw attention to what he saw as a sentencing issue and his doubt over the efficacy of behaviour orders.

\section{The consultation on introducing an SPO}

Three months after the debate, the Home Office published a consultation paper entitled 'Introducing a Stalking Protection Order' ${ }^{40}$ The consultation was open to the public for eight weeks. The Paper emphasised that the Home Office would be 'particularly pleased' to hear from some groups to include victims of stalking, organisations representing victims, the police, criminal justice practitioners and local authorities. ${ }^{41}$

\footnotetext{
${ }^{37}$ HC Deb vol 509 col 130517 September 2015.

38 ibid.

${ }^{39}$ Policing and Crime Act 2017, s 175.

${ }^{40}$ Home Office, Consultation n 12 above.

${ }^{41}$ Home Office, Consultation n 12 above, 5.
} 
The Consultation Paper narrowed Bradley's suggestion of a stalking and harassment protection order to argue there was a 'gap in the law' related to the early stages of stranger stalking in particular. ${ }^{42}$ It would have been difficult for the Paper to sustain a case for a more general order. As it acknowledged, there are already a multitude of behaviour orders that can target stalking by someone close to the victim. These include domestic violence protection orders (DVPOs); ${ }^{43}$ non-molestation orders; $;{ }^{44}$ civil restraining orders; ${ }^{45}$ and restraining orders on conviction ${ }^{46}$ and on acquittal. ${ }^{47}$ The Home Office maintained that the first two orders could not be used in the case of stranger stalking because they require a relationship between the parties. Civil restraining orders were considered problematic because they cannot impose positive obligations and can only be applied for by the victim, not the police. Restraining orders on conviction and on acquittal were rejected because they come too late in the process: after a prosecution has been brought. In essence, the Home Office argued that the then available behaviour orders either did too little or came too late. ${ }^{48}$

The argument in the Consultation Paper raises two issues. First, the Home Office subtly set parameters on the debate. The debate was not how to tackle stalking, but instead how to use behaviour orders to tackle stalking. Eight out of the ten consultation questions posed concerned the reform of current behaviour orders or the introduction of an SPO. ${ }^{49}$ This considerably

\footnotetext{
${ }^{42}$ Home Office, Consultation n 12 above, 5 and 9.

${ }^{43}$ Crime and Security Act 2010, s 24 and s 27.

${ }^{44}$ Family Law Act 1996, s 42.

${ }^{45}$ Protection from Harassment Act 1997, s 3A.

46 ibid s 5 .

${ }^{47}$ ibid s 5A.

${ }^{48}$ Home Office, Consultation n 12 above, 12-13.

${ }^{49}$ The other two questions address investigative issues and problems with identifying cases of stalking early, but they do not follow from the discussion in the Consultation Paper. Home Office, Consultation n 12 above, 14.
} 
narrowed the intellectual space in which a strategy to tackle stalking could be developed. ${ }^{50}$ The stalking debate did not have to be narrowed. Two premises and a conclusion were set out in the Consultation Paper.

- Stalking is a serious crime that affects a large number of people.

- There are behaviour orders that target some, but not all, types of stalking.

- Therefore, Government needs to introduce more behaviour orders to tackle stalking.

Surely, an equally plausible conclusion drawn from the two premises - more in keeping with Chalk's comments in debate - is that stalking continues despite current behaviour orders and, therefore, a different response (perhaps educational or situational) is needed. The important point for now is that such an alternative was just not considered in the Consultation Paper, which sets out its topic and scope as follows.

Topic of this consultation: The consultation seeks views on the introduction of new measures to offer better protection to victims of "stranger stalking" in particular. Scope of this consultation: This consultation is specifically focused on whether the introduction of a new civil Stalking Protection Order would offer further protection to victims of stalking generally and in particular victims of "stranger stalking". 51

The focus is on the behaviour orders which are available and their limitations, not on why stalking continues to be a significant problem despite the available responses. This is limiting and somewhat peculiar given the Paper later states, 'We are also aware of cases where stalkers have persistently breached restraining orders.' 52

Perhaps the Home Office's focus on behaviour orders is explicable because one of their then ministers had already endorsed such an approach in Parliament and Government had relied on the model frequently. In the years prior to the consultation, behaviour orders had been proffered

\footnotetext{
${ }^{50}$ As Adrian Barton and Nick Johns argue, much in criminal justice policy turns on how exactly a problem is conceptualised by policymakers. A. Barton and N. Johns, The Policy-Making Process in the Criminal Justice System (Oxford: Routledge, 2013) 39-42.

${ }^{51}$ Home Office, Consultation n 12 above, 5.

${ }^{52}$ Home Office, Consultation n 12 above, 11.
} 
by Government as a response to sexual offences; ${ }^{53}$ psychoactive substances; ${ }^{.54}$ and slavery and human trafficking, ${ }^{55}$ amongst other offences. ${ }^{56}$ Yet there is a difference between explaining the narrowing of the debate by the Home Office, and justifying it. Such narrowing can only make it harder to tackle stalking. The narrowing is particularly disappointing in light of a claim made by Theresa May MP, then Home Secretary, in her foreword: 'This consultation does not prejudge the outcome or next steps. ${ }^{57}$ Perhaps the Home Office did not intend for the Consultation Paper to prejudge Government's next steps, but its effect was to do just that.

The second issue with the Consultation Paper is that it left uncertain what the exact purpose of the SPO would be and thus what behaviour it would regulate. This uncertainty is wellcaptured in the following quotation:

We are therefore concerned that a gap may exist in measures available to protect victims of 'stranger stalking' in particular and to intervene early with these perpetrators and prevent these deeply entrenched obsessions from developing. ${ }^{58}$

The uncertainty turns on two axes. First, was the SPO meant to target stalking in general or stranger stalking? Much of the justificatory work in the Paper was on the 'gap in the law' in respect of behaviour orders capacity to respond to stranger stalking, not stalking generally. ${ }^{59}$ Yet the Consultation Paper did not rule out a more general order.

\footnotetext{
${ }^{53}$ Sexual Offences Act 2003, s 103A and s 122A as amended by the Anti-social Behaviour Crime and Policing Act 2014, Sched 5.

${ }^{54}$ Psychoactive Substances Act 2016, ss 18-19.

${ }^{55}$ Modern Slavery Act 2015, ss 14 and 23.

56 There must be at least a degree of truth in James Ogg's claim that policymakers have 'sleepwalk[ed]' to a proliferation of behaviour orders: J. Ogg, Preventive Justice and the Power of Policy Transfer (Basingstoke: Palgrave Macmillan, 2015) ch 8.

${ }^{57}$ Home Office, Consultation n 12 above, 3.

${ }^{58}$ Home Office, Consultation n 12 above, 9.

${ }^{59}$ Home Office, Consultation n 12 above, 11-13.
} 
Secondly, it is somewhat unclear whether the supposed gap in the law was caused by limits on the substantive criminal law or due to issues with the criminal process. ${ }^{60}$ The SPO could apply to behaviours not previously regulated and thus extend beyond current offences, it could apply when current offences could apply but are hard to prove and/or it could apply in circumstances when a charge for an offence was being prepared. The types of behaviour that would trigger the order was thus left open to question. This uncertainty was furthered by the failure of the Harassment Act 1997, as amended, to define stalking. ${ }^{61}$ When stalking itself is undefined, it is harder to discern what constitutes a behaviour antecedent to stalking or early stage stalking. The uncertainty that surrounds the precise purpose of the SPO will be considered further in the next section. It is sufficient here to note that the Home Office did not pose a consultation question to clarify the circumstances in which an order could be or ought to be sought.

In sum, the Consultation Paper was problematic for two reasons. First, it narrowed the issue of tackling stalking to tackling stalking through behaviour orders. Secondly, it offered little clarity over what gap in the law exactly the SPO was meant to close. Our attention can now turn to the Home Office's later Summary of Responses so as to examine the consequences of these problems.

\section{The Summary of Responses}

The Home Office published a Summary of Responses and a corresponding Impact Assessment in December 2016. ${ }^{62}$ Important findings from the consultation include the following.

- 69 per cent of respondents did not think current measures protected victims of stalking sufficiently.

\footnotetext{
${ }^{60}$ Home Office, Consultation n 12 above, 11.

${ }^{61}$ For comment, see N. MacEwan, 'The New Stalking Offences in English Law: Will they Provide Effective Protection from Cyberstalking?' [2012] (10) Crim LR 767.

${ }^{62}$ Home Office, Summary n 13 above; Home Office, Impact Assessment n 13 above.
} 
- The issue with using current measures to tackle stalking consultees most frequently cited by respondents was the inconsistent response of the criminal justice system.

- 80 per cent of respondents thought breach of an SPO should be an offence.

- 69 per cent of respondents thought a new order should protect victims of harassment as well as stalking. ${ }^{63}$

The Summary announced plans to introduce the SPO at the next legislative opportunity. ${ }^{64}$ In this section, I argue that the narrowing of the debate led to a position where the Home Office had little option but to admit the consultation had failed or to introduce an order of questionable efficacy and unclear purpose.

Respondents to the consultation provided information and argument which raised important questions about the capacity of the SPO to address early stage (stranger) stalking. I emphasise here that my claim is not that these responses definitively evidenced that an SPO would not work, but that they presented credible concerns about the likely efficacy of introducing the order. A number of consultation responses highlighted that stalking often goes unreported for long periods by victims. Having consulted with local service providers, Vera Baird, then Police and Crime Commissioner for Northumbria, responded: 'A victim will generally experience numerous incidents of stalking behaviour before overcoming their fears and approaching the police for help. ${ }^{65}$ In keeping with this sentiment, Katy Bourne, Police and Crime Commissioner for Sussex, remarked,

From working with specialist services in Sussex, the Commissioner understands that victims do not tend to report to the police until there have been approximately 100 incidents of stalking. ${ }^{66}$

\footnotetext{
${ }^{63}$ Home Office, Summary n 13 above, 6-8.

${ }^{64}$ Home Office, Summary n 13 above, 9.

${ }^{65}$ V. Baird, 'Commissioner's Response to the Home Office Consultation - Introducing a Stalking Protection Order' (2016) at http://www.northumbria-pcc.gov.uk/commissioners-response-to-the-home-office-consultationintroducing-a-stalking-protection-order/.

${ }^{66}$ K. Bourne, 'Home Office - Consultation on the Introduction of a Stalking Protection Order' at
} 
This figure of 100 incidents was also given by Paladin - an advocacy service for victims of stalking - in reliance on a study conducted by Lorraine Sheridan in $2005 .{ }^{67}$ If victims do not go to the police until patterns of stalking are entrenched, what use is a tool that allows for state intervention at an earlier stage? This point has particular salience if the SPO is intended to apply to behaviours that precede stalking or early stage stalking.

A plausible response to the late reporting argument is that a victim of early stage stalking may feel more comfortable approaching police if they knew early and non-criminal intervention was available. Yet neither the late reporting of stalking nor the possibility of earlier reporting in consequence of enacting the SPO is considered in detail in the Summary of Responses which only goes as far as to state: 'Other comments included...victims being reluctant to report cases until the stalking behaviour has escalated.' ${ }^{68}$

Another point related to the efficacy of the proposed SPO must be addressed: specifically, the assumption that the imposition of a behaviour order will prevent the targeted behaviour. This assumption was critiqued vociferously by Paladin in both their briefing for the Home Office and in their consultation response:

A piece of paper on its own will not protect a victim from a fixated and obsessive stalker. We know this from our cases. Restraining orders are continuously breached by stalkers and breached multiple times and not enforced. ${ }^{69}$

https://www.sussex-pcc.gov.uk/media/2696/home-office-consultation-on-the-introduction-of-a-stalkingprotection.pdf.

${ }^{67}$ Paladin, 'National Stalking Advocacy Service Response to the Home Office Consultation on New Protective Orders' (January 2016) at http://paladinservice.co.uk/paladin-response-to-the-home-office-consultation-on-neworders-for-stalkers/.

${ }^{68}$ Home Office, Summary n 13 above, 8.

${ }^{69}$ Paladin, 'Response to Consultation' n 67 above; Paladin, 'Paladin Briefing for the Home Office Consultation on Orders for Stalkers' (2016) at http://paladinservice.co.uk/paladin-response-to-the-home-office-consultationon-new-orders-for-stalkers/. 
The continued risk of breach was also noted in a report Chalk co-authored with Richard Graham MP after he had raised the issue of sentencing stalkers in Parliament. The Report states:

It has become apparent during this research that those acting obsessively frequently show themselves unwilling or unable to comply with current orders of the court. Restraining orders and bail conditions already exist that are not effective against stalkers as many of our cases show. ${ }^{70}$

Knight's campaign of stalking, for example, did not cease when a restraining order was imposed on him. As above, the Home Office also acknowledged this limitation in its Consultation Paper. ${ }^{71}$

The Home Office engaged with the likely efficacy of the SPO in its Impact Assessment. The Assessment draws an analogy to a 2013 pilot study on the effectiveness of DVPOs. ${ }^{72}$ The Impact Assessment acknowledges twice, ${ }^{73}$ that the DVPO Pilot found an 11 per cent reduction in victimization when those who received a DVPO were compared to those who were arrested with no further action. ${ }^{74}$ The Pilot was a substantial qualitative and quantitative analysis of three police force areas that assessed the implementation, value for money and effectiveness of DVPOs along with stakeholder perspectives on the order. ${ }^{75}$

The reliance placed on the DVPO Pilot requires scrutiny. First, the Pilot explicitly comments that,

\footnotetext{
${ }^{70}$ A. Chalk and R. Graham, Stalking: The Case for Extending the Maximum Penalty (2016) 10.

${ }^{71}$ Home Office, Consultation n 12 above, 9.

${ }^{72}$ Home Office, Impact Assessment n 13 above, 4 referring to Home Office, Evaluation of the Pilot of Domestic Violence Protection Orders (Research Report 76, Home Office, November 2013).

${ }^{73}$ Home Office, Impact Assessment $\mathrm{n} 13$ above, 6 and 8.

${ }^{74}$ Home Office, Pilot $\mathrm{n} 72$ above, 72.

${ }^{75}$ Home Office, Pilot $\mathrm{n} 72$ above, 12-15.
} 
When used at the first or second domestic violence incident, there was no statistically significant change in re-victimisation. However, since there was an apparent (although non significant) increase in re-victimisation when DVPOs were used at the first incident, this may warrant further investigation and monitoring if DVPOs were used more widely following the pilot. ${ }^{76}$

SPOs are meant to allow for intervention 'at the earliest possible opportunity. ${ }^{, 77}$ The Pilot does not appear to evidence that SPOs would reduce victimisation if the order is meant to apply to behaviours prior to a stalking offence being committed or early stage stalking. This troubling point was not acknowledged or addressed by the Home Office in its Impact Assessment. Secondly, the Pilot only compared the number of incidents of victimization and not the degree of victimization. ${ }^{78}$ It is thus possible that more serious incidents followed the imposition of DVPOs. This point is, again, not considered in the Impact Assessment. Taken together, the limitations of the DVPO Pilot and the late reporting of stalking presented serious questions about the likely efficacy of SPO.

The difficult situation the Home Office was left in resulted from the narrowing of the debate in the Consultation Paper from preventing stalking to preventing stalking via behaviour orders. No room was left for the possibility that information provided by consultees would suggest a new or reformed behaviour order was not an appropriate means by which to address (stranger) stalking. To launch a fresh consultation would have constituted an admission of failure. Given the questionable efficacy of the SPO and the fundamental importance of preventing stalking,

\footnotetext{
${ }^{76}$ Home Office, Pilot $\mathrm{n} 72$ above, 30.

${ }^{77}$ Home Office, Summary n 13 above, 9.

${ }^{78}$ Home Office, Pilot $\mathrm{n} 72$ above, 6.
} 
further research and consultation was surely the better option. Instead, the Home Office all but ignored the issue of non-reporting and presented information on the DVPO Pilot selectively. ${ }^{79}$

The Government's early commitment to introduce an SPO was not only problematic due to the question which remained over the likely efficacy of the order. As with the Consultation Paper, the Summary of Responses did not clarify the purpose(s) of the SPO and this left it uncertain when the order would be imposed. The Summary could not add further clarity because the consultation had not asked what particular circumstances or behaviours could or should trigger an application for an SPO. Would this be a measure aimed at all stalking or stranger stalking only? Would it expand the scope of behaviours that could be regulated by the state, would it overlap with existing offences or was it an interim measure to be applied for whilst a criminal investigation was underway?

Some, limited, indication of what the order will target may be drawn from an article by Amber Rudd MP published alongside the Summary of Responses. ${ }^{80}$ In the article, the then Home Secretary claimed SPOs would allow for intervention 'to stop perpetrators before their twisted obsession has a chance to escalate.' The statement indicates the bounds on when an SPO will be used. It is meant to be available when a person has a 'twisted obsession', but before they have undertaken a significant campaign of stalking. Yet this range could allow, in theory, for any or all of the three plausible purposes of the SPO to be pursued: to address behaviour antecedent to stalking, early stage stalking or as an interim measure during a criminal investigation. The article did not provide tangible examples of behaviours which fit within this

\footnotetext{
${ }^{79}$ For the related suggestion that ministers can fix questions in the context of Imprisonment for Public Protection see H. Annison, Dangerous Politics: Risk, Political Vulnerability, and Penal Policy (Oxford: Oxford University Press, 2015) 63-68.

80 A. Rudd, 'The Government will Stop Stalkers in their Tracks' (telegraph.co.uk, 7 December 2016) at http://www.telegraph.co.uk/news/2016/12/07/government-will-stop-stalkers-tracks.
} 
spectrum. Both the questions raised at the end of the previous paragraph were thus left unanswered. Could an uncle who checks his nephew's social media each day and comments on pictures receive an SPO? At this stage of the development of the order, it was unclear.

Uncertainty over when the police would pursue SPOs is troubling because the order may have serious impacts on recipients. The Consultation Paper asked both what restrictions and what requirements could be included in the order. ${ }^{81}$ The following suggestions by respondents were highlighted in the Summary of Responses: restricting recipients' online activities; tagging and monitoring recipients both online and in person; and mandatory mental health treatment. ${ }^{82}$ The Consultation Paper also asked whether breach of an SPO should be a contempt of court and/or an offence. ${ }^{83} 80$ per cent of respondents thought breach should be an offence and Government agreed. ${ }^{84}$ The serious effects of hybrid behaviour orders - coercive conditions backed by an offence - have long been acknowledged by the House of Lords ${ }^{85}$ and academic commentators. ${ }^{86}$ As the effects of the SPO are so severe, the order surely ought to have a clearer purpose and to be available only in discernible circumstances. People ought to have reasonable foresight of when their actions may result in prosecution, the imposition of coercive preventive measures, or no state intervention. It is thus disappointing that the Home Office did not put the same energy into discerning when SPOs should be pursued as it did into querying how coercive they could be.

\footnotetext{
${ }^{81}$ Home Office, Consultation n 12 above, 14.

${ }^{82}$ Home Office, Summary n 13 above, 7.

${ }^{83}$ Home Office, Consultation n 12 above, 14.

${ }^{84}$ Home Office, Summary n 13 above, 7 and 9.

${ }^{85}$ McCann n 6 above, Lord Steyn [37], Lord Hope [81]-[83].

${ }^{86}$ Most notably, A. Ashworth n 9 above.
} 
The Home Office should not have presumed that to introduce or amend a behaviour order was the best means by which to tackle stalking. By doing so, the department left itself in an unenviable position. The consultation provided evidence that brought the efficacy of the SPO into question and did not clarify what purpose(s) the order should fulfil. The Government was left with a choice: accept that the Home Office had not found an appropriate means to tackle (stranger) stalking or recommend a problematic order. Worryingly, it chose the latter.

\section{Parliamentary debate following the consultation}

Although Government had promised to introduce legislation at the earliest opportunity, the Stalking Protection Bill did not receive its first reading until July 2017. The Bill did not have its second reading until January 2018 and, in July 2018, received 35 minutes of consideration in Public Bill Committee. It was introduced as a Private Members' Bill by Wollaston following the House of Commons Ballot. ${ }^{87}$ The Bill as introduced did not differ significantly from the Act described above. In this section, I first engage with four key themes of the parliamentary debate on the SPO: the remarkable degree of support for the Bill; the Bill's place in a wider package of reform and investment to address stalking, and violence against women and girls more generally; the repeated examples of disastrous consequences of stalking; and the relationship of the SPO to the stalking offences enacted in 2012. In so doing, I query the extent to which parliamentary debate addressed the issues that remained with the SPO after consultation; namely, its questionable efficacy and its unclear purpose. Finally, I engage with a matter that was not the subject of parliamentary debate: the behaviours that the SPO may target extend beyond stranger stalking.

\footnotetext{
${ }^{87}$ On Private Members' Bills, see A. Al-Astewani, 'Reflections on the Rise and Fall of the Arbitration and Mediation Services (Equality) Bill' [2017] (Oct) PL 544, 544-546.
} 
First, the Stalking Protection Bill received cross-party support and the backing of Government. ${ }^{88}$ Only minor amendments were incorporated during the Bill's passage through Parliament, the most major of which was extending the power to apply for an SPO to the British Transport Police. ${ }^{89}$ A similar move to extend the power to apply to the Civil Nuclear Constabulary was considered, but not implemented. ${ }^{90}$ As can be expected, the policy work for the Bill was done in the Home Office, not Parliament.

The question of whether the new order would reduce stalking did not receive significant attention during debates in either chamber or in Public Bill Committee. Instead, a wave of antistalking sentiment swept through Parliament. Parliamentarians frequently used their speeches to decry the evils of stalking: 'Imagine feeling too scared to go out to get a pint of milk or walk your dog. Imagine feeling so scared that you have to move house. ${ }^{91}$ There is a risk that more nuanced critiques of preventive measures may be lost in such contexts. For example, Luciana Berger MP commented 'I, too, welcome the courage of people who have been able to speak out [about being stalked], but we should recognise that hundreds, if not thousands, of people throughout the country are unable to do so.${ }^{92}$ As another example, James Cartlidge MP queried the blurred lines between trolling and stalking in an online context. ${ }^{93}$ Neither point received significant engagement. There is a compelling simplicity to supporting the SPO, and similar

\footnotetext{
${ }^{88}$ HC Deb vol 634 col 124519 January 2018.

${ }^{89}$ HC Deb vol 649 cols 1147-1168 23 November 2018.

${ }^{90}$ HL Deb vol 795 cols 471-472 18 January 2019.

${ }^{91}$ HC Deb vol 634 col 123119 January 2018

${ }^{92}$ HC Deb vol 649 cols 1171-1172 23 November 2018.

${ }^{93}$ HC Deb vol 649 col 115123 November 2018.
} 
coercive measures that resembles Tony Blair's 'tough on crime' mantra. ${ }^{94}$ Who could be against the prevention of stalking? Who could be against the prevention of any crime? Yet the fact a coercive measure has a preventive purpose does not mean it will prevent harm and do so sufficiently to justify its imposition. As John Gardner insightfully remarked, 'it is easy to point to a harm that one's pet legislation is designed to eradicate; it is a lot harder to show that it eradicates it. ${ }^{95}$

Secondly, during debates on the Stalking Protection Bill ministers emphasized that it should not be considered in isolation. ${ }^{96}$ For example, in Public Bill Committee, Victoria Aitkens MP, - then a Home Office junior minister - drew attention to an increase in funding of $£ 4.1$ million for the police and plans for more multi-agency intervention to address stalking. ${ }^{97}$ Likewise, the role of the SPO in wider plans to tackle violence against women and girls was set out by ministers in debates that did not directly concern the Stalking Protection Bill such as on digital crimes, ${ }^{98}$ and funding women's refuges ${ }^{99}$ It is sensible to situate a Bill within its wider context; particularly when a social problem will require more than new law to be solved. Such situation

\footnotetext{
${ }^{94}$ See similarly, R. Ananian-Welsh, “If at First you Don't Succeed...”: Effectiveness and the Evolution of Preventive Organised Crime Measures' in T. Tulich et al (eds), Regulating Preventive Justice: Principle, Policy and Paradox (Oxford: Routledge 2017).

${ }^{95}$ J. Gardner, 'Douglas Husak, Overcriminalization: The Limits of the Criminal Law' (Notre Dame Philosophical Reviews 2008) at https://ndpr.nd.edu/news/overcriminalization-the-limits-of-the-criminal-law/.

${ }^{96}$ For example, Public Bill Committee (Bill 020) cols 7-8 9 July 2018. On the value of contextual assessments of the efficacy of preventive legal measures, see T. Legrand and T. Elliott 'A New Preventive Justice Framework for Assessing Counter-Terrorism Law and Policy: Integrating Effectiveness and Legitimacy' in T. Tulich et al (eds), Regulating Preventive Justice: Principle, Policy and Paradox (Oxford: Routledge 2017).

${ }^{97}$ Public Bill Committee (Bill 020) col 89 July 2018.

${ }^{98}$ HL Deb vol 776 col 152016 November 2016.

${ }^{99}$ HC Deb vol 635 col 9991 February 2018
} 
of the Bill also follows the conclusion to the Summary of Responses. The Summary referred to a review of the investigation of stalking by the College of Policing, training of CPS staff, and funding for the National Stalking Helpline. ${ }^{100}$ Yet the Home Office did not consult on how the SPO would fit into wider legal reform, policy development and funding changes. Does the funding required to make the SPO effective mean the order should not be introduced? ${ }^{101}$ In what circumstance is a prosecution to be preferred to the imposition of an SPO? If Government's response to stalking is to be joined-up, more consultation should have been undertaken on if and how the SPO should be integrated into wider reforms.

Thirdly, throughout the debates on the Bill, parliamentarians gave examples of the disastrous consequences that could follow from stalking. Neil O'Brien MP gave the example of the murder of Alice Ruggles following a campaign of stalking by Trimaan Dhillon. ${ }^{102}$ Baroness Gale gave the example of the murder of Jeanette Goodwin following a campaign by Martin Bunch. ${ }^{103}$ Such examples provide context on how serious a matter stalking is, but, in a sense, they go in the wrong direction. The examples are of behaviours which may follow from stalking, not of behaviours antecedent to stalking or at the early stages of it. ${ }^{104}$ By comparison, there was a lack of examples of the circumstances in which an SPO could or should be sought, or, indeed, when it should not be sought. Parliamentarians repeatedly asked if the SPO could

\footnotetext{
${ }^{100}$ Home Office, Summary n 13 above, 9.

${ }^{101}$ For instance, funding increased court time, monitoring of compliance with SPO restrictions, and to provide appropriate facilities for requirements to be fulfilled.

${ }^{102}$ HC Debs vol 649 col 117523 November 2018.

${ }^{103}$ HL Debs vol 795 col 46918 January 2019. Such examples were also relied on in the Public Bill Committee: Public Bill Committee (Bill 020) col 39 July 2018.

${ }^{104}$ At least, this is how the examples tended to be used in Parliament, see the references in the previous two footnotes. It is, of course, possible that a relatively short period of stalking could result in murder or other extremely serious consequences.
} 
be applied to incidents that occurred online, and ministers confirmed that it could. ${ }^{105}$ People can use the internet, and in particular social media, to observe and interact with each other in a myriad of different ways: they can look at photos of another organised chronologically, write to each other privately and publicly, make public statements, and share locations and interests amongst many other things. Interactions on social media thus allow for a useful test of how the SPO may be used in practice.

$\mathrm{D}$ and $\mathrm{V}$ have met at a party, do not know each other well, but have mutual friends. V's social media settings mean the friends of her friends can see her profile. $\mathrm{D}$ is attracted to $\mathrm{V}$; he looks up her profile and asks her on a date via the site. V declines D's advances and the conversation stops. D, nonetheless, continues to search for and view pictures of $\mathrm{V}$ every day over the next month. In these circumstances, could the police apply for an SPO against D? As above, the three requirements to impose an SPO are that D has carried out acts associated with stalking, D poses a risk associated with stalking and the order is necessary to protect another person. ${ }^{106}$ The behaviour requirement does not set a high threshold. Contacting a person and watching a person are given as indicative examples in section 2A of the Protection from Harassment Act 1997. As such, D's message to V and/or his continued viewing of her pictures would likely satisfy this requirement.

To satisfy the second imposition requirement, D would not have to cause harm, but to pose a risk of psychological or physical harm. Continued observation of a person after they had spurned the observer's advances could be taken to present a risk of psychological harm. It is worth emphasising that that the 2019 Act does not require a significant risk of serious harm, but only a risk of some harm. It would also not matter that looking at photos to which D had access could be harmless in other circumstances if it could be shown D knew or ought to have

\footnotetext{
${ }^{105}$ For instance, HL Deb vol 795 cols 461-462, and 47518 January 2019.

1062019 Act, s 2(1).
} 
known the act was unwelcome. Here an issue may arise as to the impact of social media privacy settings on the question of whether something is unwelcome. Can D have continued access to V's photos, and it be said his attention is unwelcome? An intuitive answer may be yes, in the same way that if two people have access to a public space D should know that continued observations of $\mathrm{V}$ are unwelcome after she had spurned his advances. A further complexity, however, of the online context is that V has explicitly consented to allow a class to which $\mathrm{D}$ belongs - friends of friends - to view her profile and has not blocked D's access in particular. ${ }^{107}$ It is possible that $\mathrm{D}$ would satisfy the risk associated requirement. Though the uncertainties of the interaction of social media settings and the requirement are troubling.

The same uncertainties may affect the applicability of the third imposition requirement. Could an SPO be said to be necessary to protect V if she could, but had not, blocked D's access to her photos? If the court believed some intervention was necessary - either a narrow SPO or that V changed her settings - would it impose the order? Further uncertainty is added by the satisfaction of all three requirements only allowing the court to impose an SPO, but not obligating it to do so. ${ }^{108}$ There are clear complexities with the application of the SPO imposition requirements and, in particular, with how these requirements will interact with social media settings. These issues were not engaged with sufficiently in Parliament. Instead parliamentarians focused on condemning stalking and the disastrous consequences that can follow from it. It is now clear the SPO may be used in response to online conduct, but it is less clear what online conduct the order will be used in response to. Significant work has been left to the courts in this regard.

\footnotetext{
${ }^{107}$ Stalking is, of course, not the only sphere in which complexities related to consent may arise. Useful comparison may be drawn here to consent and sexual offences on which see D. Ormerod and K. Laird, Smith, Hogan and Ormerod's Criminal Law (Oxford: OUP, 15th ed, 2018) 757-782.

1082019 Act, s 2(1).
} 
Fourthly, the relationship of the SPO and the stalking offences introduced in 2012 was repeatedly commented on by parliamentarians. Chalk emphasised the SPO should be seen as an additional tool, not as an alternative to imprisonment. ${ }^{109}$ Kevin Foster MP likewise emphasised the order would not cover behaviours within the scope of existing offences and would thus be 'an expansion not an alternative. ${ }^{110}$ Wollaston suggested the order could be used when a prosecution was being prepared. ${ }^{111}$ Baroness Bertin - who sponsored the Bill in the House of Lords - stated the order could be used when the criminal standard had not been met, but the behaviour was 'at risk of escalating'. ${ }^{112}$ These comments do not provide clarity as to the precise purpose of the SPO, be it as an interim measure during a criminal investigation or be it to address behaviour antecedent to stalking or early stage stalking. Instead, the comments offer some degree of support for each possible purpose. Given the continued uncertainty over the purpose of the SPO in Parliament, it is important that we examine further how the order could be used in practice and how it may overlap with the existing stalking offences.

The stalking offence in section 2A of the Protection from Harassment Act 1997 requires the offender to undertake a course of conduct that amounts to harassment that he knows, or ought to have known, amounted to harassment. ${ }^{113}$ To be imposed, the SPO does not require such a course of conduct. The Act thus allows the police to apply for an order in circumstances where a stalking offence has not been committed. This, of course, does not preclude an SPO from being applied for where a stalking offence could be charged. Yet the capacity of the SPO to

\footnotetext{
${ }^{109}$ HC Deb vol 654 col 124119 January 2018.

${ }^{110}$ HC Deb vol 654 cols 1241-1242 19 January 2018.

${ }^{111}$ HC Deb vol 649 col 117123 November 2018.

${ }^{112}$ HL Deb vol 795 col 45618 January 2019.

${ }^{113}$ Protection from Harassment Act 1997, ss 2A(1)(a) and 1(1).
} 
regulate behaviour antecedent to stalking or early stage stalking in practice remains open to question because Parliament did not address the significant limitations on the reporting of stalking described above.

A further possibility is that SPOs will be used as an interim measure when a criminal investigation is underway. ${ }^{114}$ The trouble with using the SPO to this end is that the order must last for a minimum of two years, and the police need to consent to an earlier discharge. ${ }^{115}$ This could impact on the necessity requirement to impose the order. Could it be necessary to impose an order for a minimum of two years if a prosecution was likely to occur within six months? If the SPO was intended as an interim measure prior to a prosecution it should end automatically on prosecution or on completion of the trial. By comparison, the DVPO, which is intended as an interim measure, can only last for a maximum of 28 days. ${ }^{116}$ In addition, the explanatory notes to the Stalking Protection Bill gave examples of requirements that may be imposed on the recipient that do not sit comfortably with the prospect of the recipient contesting a future criminal trial: perpetrator intervention programmes, mandatory mental health assessments and participation in restorative justice. ${ }^{117}$ It is hard to see how restorative justice in particular is compatible with the order being an interim measure prior to a contested trial. If the recipient does engage in restorative justice, they may incriminate themselves. If the recipient does not engage in restorative justice, they may be prosecuted for breach of the SPO. Though the

\footnotetext{
${ }^{114}$ For the avoidance of doubt, I am referring to the use of a final SPO as an interim measure during a criminal trial, not the more limited interim SPO available under section 5 of the 2019 Act.

1152019 Act, ss 3-4.

${ }^{116}$ Crime and Security Act 2010, s 28(10)(a)-(b); Home Office, Domestic Violence Protection Notices (DVPNs) and Domestic Violence Protection Orders (DVPOs) Guidance (2016) para 2.3.

${ }^{117}$ Explanatory Notes to the Stalking Protection Bill (HL Bill 145) para 27.
} 
purpose the SPO may best be able to fulfil is that of an interim measure during a criminal investigation, its legal framework does not appear to be designed with this purpose in mind. ${ }^{118}$ The ambiguity over what 'gap in the law' the SPO was meant to close may not have been answered in Parliament, but the 2019 Act shows the SPO retains the potential to be used as an interim measure, an alternative to prosecution and to extend the behaviours that may be regulated by the state. Given the late reporting of stalking and the structural impediments to using the SPO as an interim measure, perhaps the SPO will be used for some other purpose in practice. Such uncertainty as to the purpose of the order as enacted is of particular concern given how coercive a measure it is.

A further issue with the Stalking Protection Bill was not discussed in Parliament. The Consultation Paper queried whether victims of stranger stalking in particular had sufficient protection. A perceived gap with respect to stranger stalking was central to the early justification of the SPO. Yet the term 'stranger' is not used in the 2019 Act. The SPO could also be used against those with an existing or prior relationship to the victim. The initial problem is that the order introduced is broader in its applicability than that which the Home Office had sought to justify. Even if one is of the view that sufficient work had been done to justify a stranger stalking protection order, this is not what was enacted. Further issues may result from this broad applicability: the SPO is more likely to overlap with existing orders such as non-molestation orders and the domestic abuse protection order proposed in the Domestic Abuse Bill. ${ }^{119}$ As above, the issue with responses to stalking most frequently cited by consultees was the inconsistent response of the criminal justice system. ${ }^{120}$ Given the SPO may

\footnotetext{
${ }^{118}$ Compare to L. Zedner, 'Terrorizing Criminal Law' (2014) 8(1) Criminal Law and Philosophy 99, 108.

${ }^{119}$ Domestic Abuse Bill 2017-19 (HC Bill 422), cls 24-52.

${ }^{120}$ Home Office, Summary n 13 above, 7.
} 
overlap with other behaviour orders and both the current stalking offences, it has the potential to further this problem as opposed to resolving it.

\section{Beyond the stalking protection order}

In this section, I make two more general points on hybrid behaviour orders that follow from the above analysis of the Stalking Protection Act 2019. The first relates to the language of 'prevention' and 'protection' that is central to discussions of behaviour orders. These two terms form part of the name of many behaviour orders to include female genital mutilation protection orders, ${ }^{121}$ forced marriage protection orders, ${ }^{122}$ serious crime prevention orders, ${ }^{123}$ sexual harm prevention orders, ${ }^{124}$ slavery and trafficking prevention orders, ${ }^{125}$ terrorism prevention and investigation measures, ${ }^{126}$ and domestic violence protection orders. ${ }^{127}$ Behaviour orders, are also commonly referred to as 'preventive orders' or 'civil preventive orders' in academic commentary. ${ }^{128}$

\footnotetext{
${ }^{121}$ Female Genital Mutilation Act 2003, Sched 2 paras 2-3.

${ }^{122}$ Family Law Act 1996, s 63A.

${ }^{123}$ Serious Crime Act 2007, ss 1 and 19.

${ }^{124}$ Sexual Offences Act 2003, s 103A(2)-(3).

${ }^{125}$ Modern Slavery Act 2015, ss 14-15.

${ }^{126}$ Terrorism Prevention and Investigative Measures Act 2011.

${ }^{127}$ Crime and Security Act 2010, s 27.

${ }^{128}$ See, for instance, S. Shute, 'The Sexual Offences Act 2003: (4) New Civil Preventative Orders - Sexual Offences Prevention Orders; Foreign Travel Orders; Risk of Sexual Harm Orders' [2004] (6) Crim LR 417; A. Ashworth and L. Zedner, Preventive Justice (Oxford: OUP 2014) ch 4; H. Carvalho, The Preventive Turn in Criminal Law (Oxford: OUP 2017) 6-8; P. Ramsay, The Insecurity State: Vulnerable Autonomy and the Right to Security in the Criminal Law (Oxford: OUP 2012); N. Lacey, In Search of Criminal Responsibility: Ideas, Interests, and Institutions (Oxford: OUP 2016) 158-161; I. Dennis, 'Security, Risk and Preventive Orders' in G. Sullivan and I. Dennis, Seeking Security: Pre-Empting the Commission of Criminal Harms (Oxford: Hart 2012).
} 
The widespread adoption of the language of prevention and protection gives rise to a problem. Government look to justify the coerciveness of behaviour orders (in the conditions they impose and the effects of breach) through their preventive status. In its response to the stalking consultation, Government made clear the enactment of the SPO would be justified by the need 'to protect victims and stop perpetrators at the earliest opportunity. ${ }^{\text {129 }}$ Likewise, Home Office guidance on the sexual harm prevention order provides its 'fundamental purpose... is to protect the public from sexual harm'. ${ }^{130}$ Yet the above criticism of the SPO shows Government and Parliament were unclear in the specifics of what the SPO would do and the evidence of its likely efficacy remains open to question. The common acceptance of the language of prevention and protection risks shrouding the empirical and normative work that remains to be done on hybrid behaviour orders. What is the preventive efficacy of hybrid behaviour orders? Is their preventive efficacy sufficient to justify their coerciveness? If we label behaviour orders preventive or protective without engaging with both questions, it may lead us to assume they are justified when they are not.

The second point concerns the varied requirements to impose behaviour orders and the relationship of these requirements to the question of which evidential rules should apply when these orders are pursued. Some context on the evidential rules and standard to be applied when hybrid behaviour orders are pursued is needed. In the lead decision of $R$ (McCann) $v$ Manchester Crown Court, the House of Lords held the ASBO was not a penalty and therefore the heightened criminal fair trials safeguards, such as the right to cross-examine witnesses, were not required in proceedings for its imposition. ${ }^{131}$ The Court also held that, in effect, the criminal evidential standard of beyond reasonable doubt should be applied in proceedings for

\footnotetext{
${ }^{129}$ Home Office, Summary n 13 above, 9.

${ }^{130}$ Home Office, Guidance on Part 2 of the Sexual Offences Act 2003 (2018) 37-38.

${ }^{131}$ McCann n 6 above, [40] (Lord Steyn), [84] (Lord Hope), [115] (Lord Hutton).
} 
an ASBO because of the 'seriousness of matters involved'. ${ }^{132}$ A compromise position was therefore reached: civil rules were to be used, but the criminal standard would apply. There has since been a string of cases that assess whether proceedings for the grant of different behaviour orders, and similar measures, have serious enough consequences to require the heightened evidential standard. ${ }^{133}$ In addition, there has been significant commentary on whether proceedings for behaviour orders should employ the criminal fair trial safeguards. For instance, Andrew Ashworth notably queried whether the decision in McCann constituted a subversion of the right to a fair trial. ${ }^{134}$ More recently, Mark James and Geoff Pearson have argued that the case law and legislation on football banning orders has developed in such a way that they should be considered penalties. ${ }^{135}$

The development of and final form of the SPO shows that it is not only the courts that have a role in establishing what evidence is required to impose behaviour orders. The evidence needed to impose a behaviour order is not only affected by what evidential standard and rules apply. It is also affected by the contents of the relevant imposition requirements. As above, the SPO does not have a course of conduct imposition requirement like that which applies to the section 2A stalking offence. The order also only requires a risk of relevant harm to be shown under its second imposition requirement, not a high risk of serious harm. In setting these standards, Government and Parliament thus also affect how easy it is to impose an SPO. It may, for

\footnotetext{
${ }^{132}$ McCann n 6 above, [37] (Lord Steyn), [81]-[83] (Lord Hope), [114] (Lord Hutton).

${ }^{133}$ Compare Chief Constable of Merseyside v Harrison [2007] QB 79 to Commissioner of Police of the Metropolis v Ebanks (2012) 176 JP 751.

${ }^{134}$ Ashworth n 9 above.

${ }^{135}$ M. James and G. Pearson, '30 Years of Hurt: The Evolution of Civil Preventive Orders, Hybrid Law, and the Emergence of the Super-Football Banning Order' [2018] (Jan) PL 44.
} 
instance, be easier to evidence a risk of some harm beyond reasonable doubt than it would be to evidence a high risk of serious harm on the balance of probabilities.

If we focus on the evidential standards and rules for the imposition of behaviour orders, we risk missing out on the significant variance in their imposition requirements. For instance, to satisfy the backward-looking requirement to impose a sexual risk order the defendant must only have 'done an act of a sexual nature'. ${ }^{136}$ They do not need to have committed a sexual offence or, indeed, to have done anything wrongful. By comparison, to satisfy the backwardlooking imposition requirements for a criminal behaviour order, the defendant must have committed an offence and 'engaged in behaviour that caused or was likely to cause harassment, alarm or distress to any person'. ${ }^{137}$ The relevant imposition requirement for the sexual risk order may be easier to prove than those of the criminal behaviour order even if the heightened evidential standards were applied in proceedings for it. Government and Parliament can impact significantly on what evidence is needed in proceedings for behaviour orders through the imposition requirements they set. If the proceedings for the grant of behaviour orders are to be fair, we must examine not only the applicability of the criminal fair trial safeguards, but also the contents of the imposition requirements at issue. ${ }^{138}$

\section{Conclusion}

\footnotetext{
${ }^{136}$ Sexual Offences Act 2003, s 122A.

${ }^{137}$ Anti-social Behaviour, Crime and Policing Act 2014, s 22.

${ }^{138}$ A useful comparison here may be to the relationship of the elements of criminal offences and the protections of the right to a fair trial: V. Tadros and S. Tierney, 'The Presumption of Innocence and the Human Rights Act' (2004) 67(3) MLR 402; R. Kelly, 'The Right to a Fair Trial and the Problem of Pre-Inchoate Offences' [2017] (6) EHRLR 596.
} 
Government, in developing the SPO, and Parliament, in introducing the Stalking Protection Act 2019, had a laudable aim: to prevent stalking. Yet the specifics of what the SPO is intended to do remain unclear and questions remain over its likely efficacy. Given these problems, the limited critical engagement in both the Home Office consultation and in parliamentary debate is a matter of concern. The rapid production of evermore criminal law means the issues which affected the SPO may not be unique. 2019 also saw the introduction of new terrorism offences and heightened maximum sentences for existing terrorism offences; ${ }^{139}$ new voyeurism offences; ${ }^{140}$ new offences and powers related to offensive weapons; ${ }^{141}$ and a new offence that prohibits the use of wild animals by travelling circus owners. ${ }^{142}$ The development of the SPO shows that we must be able to say that both a social problem and a proposed response to it are bad. Otherwise, we risk limiting our capacity to respond to the problem effectively and fairly, and we also risk causing further problems through our response.

The development of the SPO also allows for more general insight into the proliferation of hybrid behaviour orders. As above, much of the existing research on behaviour orders has critiqued judicial assessments of whether these measures are penal. ${ }^{143}$ The focus here has been on Government and Parliament. Yet critiques of the courts, and of Parliament and Government do not need to stand in isolation. Government continues to develop hybrid behaviour orders to target criminal activity, Parliament continues to enact these orders and the courts continue to find they are not penalties. The positions of the courts, Government and Parliament, are reinforcing. So long as the courts find behaviour orders to be non-penal, there will be reason

\footnotetext{
${ }^{139}$ Counter-Terrorism and Border Security Act 2019, ss 1-11.

${ }^{140}$ Voyeurism (Offences) Act 2019, s 1.

${ }^{141}$ Offensive Weapons Act 2019, ss 1-63.

${ }^{142}$ Wild Animals in Circuses Act 2019, s 1.

${ }^{143}$ See the references at fn 9 above.
} 
for the Government to rely on the model and for Parliament to enact it. Behaviour orders are no longer a unique tool to respond to the difficulties of regulating anti-social behaviour. ${ }^{144}$ They are a normal feature of policymaking. If the courts started to find hybrid behaviour orders to be penalties, ${ }^{145}$ the model would be of less value to Government because the orders would lose their procedural advantages over the criminal law. Although Government and Parliament have been the focus of this article, the courts too have thus played an important role in cementing the hybrid behaviour order as a means of social control. ${ }^{146}$

\footnotetext{
${ }^{144}$ On which, see A. Simester and A. von Hirsch, 'Regulating Offensive Conduct through Two-Step Prohibitions' in A. von Hirsch and A. Simester (eds), Incivilities (Oxford: Hart Publishing, 2006) 175-177.

${ }^{145}$ At present this appears unlikely, see Jones $\mathrm{n} 7$ above.

${ }^{146}$ Borrowing the language of Ashworth n 9 above.
} 